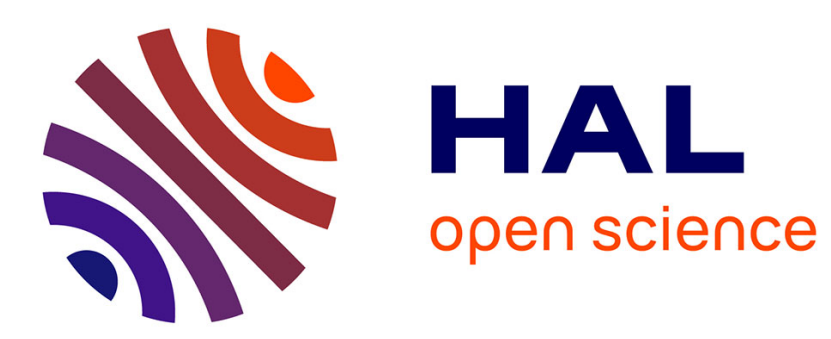

\title{
Non-Muslim citizens as foreigners within: how Ecnebi became Yabanci from the Ottoman Empire to the Turkish Republic
}

Olivier Bouquet

\section{- To cite this version:}

Olivier Bouquet. Non-Muslim citizens as foreigners within: how Ecnebi became Yabancı from the Ottoman Empire to the Turkish Republic. Middle Eastern Studies, 2017, 53 (3), pp.486-499. 10.1080/00263206.2016.1268126 . halshs-02136093

\section{HAL Id: halshs-02136093 \\ https://shs.hal.science/halshs-02136093}

Submitted on 16 Apr 2021

HAL is a multi-disciplinary open access archive for the deposit and dissemination of scientific research documents, whether they are published or not. The documents may come from teaching and research institutions in France or abroad, or from public or private research centers.
L'archive ouverte pluridisciplinaire HAL, est destinée au dépôt et à la diffusion de documents scientifiques de niveau recherche, publiés ou non, émanant des établissements d'enseignement et de recherche français ou étrangers, des laboratoires publics ou privés. 


\section{Non-Muslim citizens as foreigners within: how Ecnebi became Yabancı from the Ottoman Empire to the Turkish Republic}

\section{Olivier Bouquet}

To cite this article: Olivier Bouquet (2017): Non-Muslim citizens as foreigners within: how Ecnebi became Yabancı from the Ottoman Empire to the Turkish Republic, Middle Eastern Studies, DOI: 10.1080/00263206.2016.1268126

To link to this article: $h$ ttp://dx.doi.org/10.1080/00263206.2016.1268126

曲 Published online: 06 Jan 2017.

Submit your article to this journal $\pi$

Q View related articles $\longleftarrow$

View Crossmark data $₫$ 


\title{
Non-Muslim citizens as foreigners within: how Ecnebi became Yabancı from the Ottoman Empire to the Turkish Republic
}

\section{Olivier Bouquet}

Ottoman History, CESSMA (Centre d'Études en Sciences Sociales sur les Mondes Africains, Américains et Asiatiques), Paris Diderot University, Paris, France

\begin{abstract}
Serap the schoolteacher noticed the epigraph above the fountain. It read: 'Pious donation of Mıgdıs, son of Barad.' She could not understand. This was a foreign word, but what did it mean? Hacl Amca, who had performed the ablutions for the prayer, leant towards the fountain's basin to drink his fill. After having said 'Thank be to God,' he whispered, 'May you rest in peace, Mıgdıs Efendi.' Meanwhile, he turned toward Serap the schoolteacher and started to tell the [following] story: 'My daughter-schoolteacher, Mıgdıs is the name of the Armenian who had this fountain repaired. He was an Ottoman subject. He had established a pious foundation. Yes, Non-Muslim people of these lands, too, have created various foundations.' Serap the schoolteacher had learnt something new. ${ }^{1}$
\end{abstract}

This story takes place in Gümüşhacıköy, a village located in the region of Amasya. It appears in a schoolbook published by the Directorate General of Foundations. Its purpose is to highlight to what extent non-Muslim subjects of the sultan played an active role in 'the civilization of pious foundations' (Vakıf medeniyeti) ${ }^{2}$ that has been highly glorified by Turkey's Islamist regime in recent years. ${ }^{3}$ In the story, the schoolteacher takes an Armenian name for a foreign name. Moreover, the authors of the book mention as 'Magdis Kiregos' someone whose name was probably 'Makdisi Giragos'. ${ }^{4}$ This is a well-known fact: like many other people, Turkish citizens often experience difficulties in identifying the origins of proper names. ${ }^{5}$ Another reality is less considered by scientific studies and popular literature: in Turkey, someone who would not be considered as a foreigner Mıgdıs, an Armenian who 'was an Ottoman subject' - sometimes comes to be regarded as such. The purpose of the present article is to shed light on this reality from an historical perspective.

Since the establishment of the Republic in 1923, any non-Muslim born in Turkey, whether Greek, Armenian or Jewish, is a Turkish citizen as much as any of his/her Muslim fellows. Located at the core of Kemalist ideology, this principle was inscribed in constitutional law. As Ismet Inönü, who was a war comrade of Mustafa Kemal and became the President of the Turkish Republic after he died in 1938, once said: 'A Turk is whoever desires and loves to be so.' ${ }^{6}$ Tekin Alp who quoted him added: 'To belong to the same nation, it is not necessary to belong either to the same race or religion, but to speak the same language, share the same culture and ideals." Practically, the founding philosophy of Turkish nationalism was partly implemented through policies of 'turkification' (türkleștirme) conducted during the 1930s. However, many specialists have identified flaws 
and limitations regarding these policies, ${ }^{8}$ while others have examined the state's failure to accommodate ethno-religious diversity. ${ }^{9}$

My purpose here is to examine non-Muslim status as the result of a pre-Republican Islamic State ideology nurtured by imperial practice. In this regard, studies have often differentiated between minorities related to what was defined in the Empire as millet (lit. religious community, nation, people) and Muslim subjects. I will argue that another way to understand non-Muslims as distinctive Turkish citizens is to compare them not only with Muslims but also with foreigners. This is a difficult task since this category refers to evolving realities from the Empire to the Republic and encapsulates various emic notions. For a historian, the category of foreigner might be considered as an analytical tool only if analyzed through a rich and complex semantic field. Indeed, it articulates inner/outer spaces and encompasses modern and pre-modern terminologies. Among these, some were laid aside during the Republican times whereas others were valued by the new regime. I will here scrutinize ecnebi as an example of the former while considering yabancı as epitomizing the latter. In doing so, I will show how, decade after decade, one has been substituted by the other, in relation to the exclusion or integration of Ottoman notions such as müstemen (alien in the Ottoman Empire), zimmi (non-Muslim subject) or yaban (stranger). I will argue that this evolution has reflected the formation of less visible categories of foreigners that partly originated from the confessional imperial framework. I will show that, far from being set aside, as Kemalist ideology has long put forward, this framework has prevailed. As a result, non-Muslim Turkish citizens have often been regarded as 'foreigners within' (içerdeki yabancı). ${ }^{10}$

\section{From the Ottoman Empire to the Turkish Republic: Muslims and non-Muslims}

The Ottoman Empire was an Islamic state. It built on the socio-political difference legally drawn between Muslims and 'non-Muslims' (gayr-ı müslim) on the one side, those who lived under Muslim rule in the Empire (part of the dar al-islam, 'abode of Islam') and those who did not (dar al-harb, 'abode of war'), on the other side. The Muslims who were forced to leave their homelands were to be admitted to live in the Empire as muhacir (lit. emigrant, refugee, fugitive). ${ }^{11}$ This category refers to the Hegira (hicret). Used in various surahs of the Holy Koran, it designates all those who followed the Prophet Muhammad after he left Mecca to Medina. As these muhacir had given up their properties, they lived in a state of deepest misery. In order to help them, the Prophet had tried to spread a feeling of generosity among the Medinians. Modelling himself on Muhammad as previous Islamic monarchs had, the Ottoman sultan recognized and eulogized the muhacir condition, doing his best to welcome them in his own lands, especially the refugees who left the Caucasus in great numbers in the 1860s and the Balkans after the Ottoman-Russian war of 18771878. ${ }^{12}$ Practically, as a support from the central administration, the State requested local mobilization of local authorities. Non-Muslims were also to be welcomed within the Empire, while being called muhacir or göçmen ('immigrant, settler') - the latter was a nineteenth-century neologism that became more utilized in the $1930 \mathrm{~s}^{13}$ Since they belonged to the religions of the Book and as long as they respected the rules of the dhimma, ${ }^{14}$ they were authorized to live in the 'protected domains' (memalik-i mahruse) as zimmi. This was not true of non-Muslims who still lived in the dar al-harb. Those were generally designated 
as harbi (enemy; non-Muslim) or kâfir ('infidel, unbeliever'; pl. kefere), sometimes related to countries with which the Ottoman State had established commercial or diplomatic agreements (Fransa keferesi, Rus keferesi... ('unbelievers of France', 'unbelievers of Russia'...)). Playing a role in these relations, some merchants, travellers, diplomatic envoys, priests and pilgrims applied for admission to the Ottoman territory. Since they benefited from an individual self-conduct (aman, lit. a pardon), they were called müstemen, 'étranger(s) en pays musulman', ${ }^{15}$ 'to whom application is made for safety, quarter or amnesty'. ${ }^{16}$ This grace was altogether legally temporary and politically exceptional. ${ }^{17}$ As a matter of fact, it concerned a limited number of people, i.e. a few thousand at the end of the eighteenth century that became a few ten thousands one century later. In contrast, zimmi numbered in the millions and were more numerous than Muslim subjects in most territories of the Balkans and other parts of the Empire. ${ }^{18}$

The zimmi status primarily referred to individual designations - Yanko veled-i Pavlo bir zimmi (Yanko a zimmi son of Pavlo) - and was collective in the sense that it designated fiscal subdivisions (ehl-i zimmet, 'people of the dhimma'). During the Tanzimat ('reforms, reorganizations', 1839-1878), imperial regulations recognized hierarchically organized bodies with a decidedly political function among religious communities. From this time onward, a non-Muslim was associated with a millet according to his religion. Until the beginning of the eighteenth century, the Ottomans had been separated into two categories: the reaya were the subjects, Muslims or not, who as peasants, craftsmen or traders produced growth and paid taxes accordingly; the askeri, either soldiers, clergymen or civil servants, were exempted from taxes. Interestingly enough, within the next decades, the term reaya came to be exclusively associated with non-Muslims (gayr-ı muslim). With the Rescript of Gülhane promulgated in 1839, the disappearance of askeri privileges entailed the abolition of the reaya as a legal category. Thirty years later, the 'Law of Ottoman Citizenship' (tabiiyet-i osmaniye kanunnamesi) completely transformed the subjects of the sultan into Ottoman citizens, subjects of the State (tebaa), i.e. members of the same 'nationality' (tabiiyet), whatever their own religions. The Republican regime maintained this system, replacing the term tabiiyet by the pre-existing words vatandaşlık and yurttaşlık. Even if the first mainly corresponded to 'nationality' and the second to 'citizenship', the distinction was never clear-cut, partly because both notions were imbricated within the Turkish political system. Moreover, another word was also utilized to designate citizenship: milliyet. It derived from milli (national). Interestingly enough, milliyet was not the one chosen by the Türkiye Büyük Millet Meclisi (Grand National Assembly of Turkey) to designate the Turkish Parliament established in 1921. As Bernard Lewis once noticed: 'All citizens of Turkish Republic are of Turkish tabiyet; their milliyet however, may be Greek, Armenian, Jewish or, for the majority, Muslim and Turkish interchangeably. ${ }^{19}$ On the one hand, the Türk milleti (Turkish nation) was now considered to be the proper way to circumscribe the people who lived in the country that was officially called Türkiye. Indeed, the Constitution ratified in 1924 mentioned the Türkiye milleti (nation of Turkey). On the other hand, millet was still associated with religious categories as it was a few decades ago. ${ }^{20}$ In the meanwhile, the cemaat (lit. assembly, religious community) had become Turk (Türk milleti). ${ }^{21}$ But later on, it took some time before everyone in the country figured out this change. In the novel Karapürçek by S. Arısoy, a teacher tries to diffuse the national ideology amongst his pupils in a little village near Sakarya during the 1940s. He asks: 
- I said, Well, to whom does this flag belong, Dursun? Who are those said to be Turks?

- ?! (...)

- You have never seen it? (...)

- He has never come up to the village, Sir, he said

- Who has never come?

- The one you said was a Turk

- Right, and you, what are you, son?

- I am a Muslim, Sir

- Who taught you that?

- Hoca Efendi said so; so did we. All of us are Muslim!

- Son, you are a Muslim, I got it. All of us are Muslims. This is our religion. What is our nation? Don't you have any nation?

- I have no idea, Sir. $^{22}$

In the end, the teacher asks the same question of each pupil. Only two of them provide an answer, imprecise though. As a matter of fact, even for those Turkish citizens who were able to distinguish between their religion and their nation, they could hardly give any definition that everyone would agree on. Indeed, during the 1920s, different conceptions of the nation were in competition: first, a political/republican conception according to which a Turk was a citizen who had previously assimilated the Turkish language, culture and national ideals (dehayı milli, lit. national genius); second, an Islamist conception put forward that the Muslim people of Turkey were Turks (dine dayalı Türklük, 'Turkishness based on religion'); third, an ethnicist/racist definition confined the Turkish identity to descendants of autochthonous populations of Central Asia (Türk kökenli, 'of Turkish origin' Türk soylu, 'of Turkish race'). ${ }^{23}$

\section{Ecnebi: foreigners within the empire}

The concept of nation changed. So did the notions used to designate those who were not part of it. ${ }^{24}$ The expansion of international trade and the multiplication of foreign schools, banks, societies and chambers of commerce resulted in a growth in the number of nonOttomans living in the territories: they amounted to 250,000 according to the 1897 census. Meanwhile, since it depended upon new measures of identification and passport regulations (nizamname, 'regulations' of 1867 and 1884), the status of müstemen, as an expression of sultanic grace, became obsolete. Instead, other words were still used towards the end of the Ottoman period. Among them, Frenk (Frank) designated all Levantines, namely Roman Catholics established in the Empire for centuries, and new European migrants. It was also utilized to identify their districts. ${ }^{25}$ Ecnebi was another one that deserves careful attention.

The word ecnebi was used much more during the last Ottoman decades than in the previous centuries. ${ }^{26}$ As in Arabic (from which it originated), it encapsulated the general meaning of 'extraneous', ${ }^{27}$ i.e. from elsewhere, from another district for instance. ${ }^{28}$ As also in Arabic (ajnab), an ecneb was 'from another country'. ${ }^{29}$ Logically, the word ecnebi was utilized in the 1869 Law to designate non-Ottomans. ${ }^{30}$ More specifically, it embodied external realities or represented institutionalized authorities amongst the Ottomans. For instance, the umur-i ecnebiye were the 'foreign affairs' the reis ül-küttab ('chief of the 
chancery' or divan-i hümayun) was in charge of until the function was abolished in 1836 . In the State almanacs (salname) of the second half of the nineteenth century, the ecnebi konsolosları (foreign consuls) were the representatives of the 'foreign states' (düvel-i ecnebiye) or 'foreign countries' (memalik-i ecnebiye). ${ }^{31}$ As a müstemen, an ecnebi was admitted to the imperial domains, with regard to the benefits he was expected to provide. For this reason, he was mostly granted imperial pledges called imtiyazat-ı ecnebiye. $^{32}$ These capitulations (ahd-ı name-i hümayun) were conceived to host any subject of a foreign nation who wished to visit or reside in the Ottoman lands for a peaceful purpose. ${ }^{33}$ They were also implemented to facilitate international trade, especially to sustain imports according to the prevailing 'economic Ottoman mind'. ${ }^{34}$ After this system was installed in the fourteenth century and until it was abolished in 1914, 'foreign States registers' (düvel-i ecnebi defterleri) were set up in the Amedi kalemi (clerical office of the receiver general of correspondence addressed to the Grand Vizier) to record consular and merchant activities within the Empire together with protocols and court sentences related to their business. ${ }^{35}$ At this time, many more Levantines as well as European or Oriental Christians benefited from patents (berat) and consular protections in order to create șirket-i ecnebiye (foreign firms). ${ }^{36}$ Foreign currencies such as ecnebi kuruşu ('foreign piasters' that circulated in the middle of the seventeenth century) and ecnebi yaldız altını ('foreign gilding gold', that replaced gold coin (altın para) after $1725)^{37}$ were to bear deficiencies of Ottoman monetary units. Their circulation helped import raw materials and manufactured products as well. These were not only of European but also of Eastern origin, such as Persian tobaccos called ecnebi tönbekileri. Chambers of commerce (ecnebi ticaret odaları) appeared in the last quarter of the eighteenth century. The practice of 'foreign languages' (lisan-i ecnebiye) expanded in ports and cities. Italian was used in the eighteenth-century navy, French in nineteenth-century diplomacy or German in nineteenth-century military logistics.

However useful he might be to Ottoman trade, a 'foreign merchant' (ecnebi tüccar) was still considered a harbi, often associated with common use expressions as gâvur ('infidel', 'unbeliever') or kâfir. As in other languages, being a foreigner was foremost being a stranger: 'stranger, foreigner, alien', according to the lexicographer Sir James Redhouse. ${ }^{38}$ As in Arabic from which it originated, garib had both meanings ('strange, foreign'), ${ }^{39}$ and its derivation garabet ${ }^{40}$ was synonymous with 'strangeness' (tuhaflık). ${ }^{41}$ Moreover, ecnebi crystallized European imperialism as a Janus-face scheme - what was good for the country (business growth and economic expansion) accompanied what was not (decline of craft sectors, trade deficit, increasing public debt). A comparison might be insightfully drawn with nineteenth-century Qajar Iran: what was ajnabîy ('foreigner, stranger'; ajnabîyat, 'state of a stranger or alien') ${ }^{42}$ resulted in dividing the country between the Russian sphere of influence in the north and the English hegemony in the south. Impacted by the emergence of Turkish nationalism, the increasing European control over the Public Imperial Debt (Deyn-i umumiye) instituted in 1881, withdrawing more than a fifth of fiscal revenues, and the 1908 boycott campaign, the word ecnebi was eventually integrated into a newly shaped political framework; ${ }^{43}$ whereas an ecnebi had long been perceived as an outsider, albeit potentially useful, he was identified as a dangerous insider in cahoots with nonMuslim traders against the beneficial emergence of a 'national economy' (milli iktisat). In December 1914, the privileges previously granted to ecnebi anonim (foreign joint stock companies) and ecnebi sigorta șirketleri (foreign insurance companies) were cancelled. ${ }^{44}$ 
As economics were now to depend on politics according to Young Turk intellectuals, foreign activities of any kind were described as potentially hostile to the Turkish nation. ${ }^{45}$ As a plural, the word originated a telling neologism: ecanibgürizlik (xenophobia). ${ }^{46}$ A decade later, inspired by his predecessors, Mustafa Kemal ordered that economic autarchy be implemented at any cost. In 1954, the last payments of the Imperial debt marked the resolute end of the direct intervention of the 'great powers' (düvel-i ecnebiye).

\section{Foreign languages: new definitions}

As a political paradigm or an economic concept, ecnebi crystallized the profound terminological changes that took place during the first decades of the twentieth century. Until then, Arabic, Persian and Turkish were characterized and praised as the elsine-i selase (three languages) that dominated religious, scientific and literary disciplines. These were differentiated from elsine-i ecnebiye (foreign languages), such as French, a language Ahmed Cevdet had no choice but to learn secretly in the 1840 s as a madrasah student. ${ }^{47}$ This differentiation was redefined during the Young Turk period, after a 'linguistic Turkism' (lisani türkçülük) had emerged in the 1880 s. ${ }^{48}$ As a result, in 1923, Ahmed Cevat depicted any language except Turkish as a foreign language, including Arabic and Persian. ${ }^{49}$ This came up with a newly scientific separation promoted by specialists between 'pure Turkish' (öz türkçe) and Ottoman Turkish. The former was officially promoted under the Kemalist regime, after it had been labelled by nineteenth-century scholars such as Ibrahim Şinasi as safi türkçe (pure Turkish). ${ }^{50}$ The Turks still used the latter, even if many Kemalist ideologists called upon their people and themselves not to do so. In Republican historiography, the Ottomans were defined as an un-Turkish group regrettably ruled by a corrupt clique. The imperial household (hanedan) was excluded from the national community and forced into exile in 1924. The lisan-i osmani (Ottoman language) was downgraded as a foreign language within the nation, as the famous nationalist intellectual Ziya Gökalp explained in his Türkçülügün Esasları (The Principles of Turkism) published in 1923..$^{51}$ Even if he did not favour them in his global philosophy of Turkish nationalism, he recommended that foreign words might be integrated into the national (milli) language yet to be built. ${ }^{52} \mathrm{He}$ argued that many of them were already employed by the people and would be utilized in the future accordingly. ${ }^{53}$ In other words, they would end up as milli words for the reason they had previously been adopted by the lisan-i osmani (tiyatro, roman, telefon, vapur...). Following the model of the Ottoman lexicologist Şemseddin Sami, ${ }^{54}$ Ziya Gökalp distinguished Turkish and Ottoman the same way he differentiated between two kinds of foreign languages: on the one hand, ecnebi/European languages encapsulated a high degree of strangeness to the Turkish peoples; on the other hand, foreign languages such as Arabic and Persian, respectively, arabça ('Arabic') and acemce ('Persian', instead of farisi, id.) were not so strange due to the fact that, for better or for worse, they had been partly assimilated by the lisan-i osmani. Each category had to be addressed accordingly: strange ( $r$ ) or not, what was to be linguistically assimilated by the nation was dependent on the people's use of it; what eventually turned out to be alien to practical use (Ottoman, consequently Arabic and Persian) had to be definitively removed. No matter the consequences: 'because those words which penetrated the dictionary of a nation have become the property of the national language of that nation' (çünkü bir miletin kamusuna girer kelimeler artık o milletin milli lisanına mal olmuștur). 


\section{Yabancr: the empire}

Indeed, not only did the Turkish linguistic nationalism take into account changes that had taken place during the last Ottoman decades, but it resolutely emphasized many of them. For instance, the word müstemen did not correspond to any kind of practice any longer. ${ }^{55}$ It faded away to an extent which the author of a recent Masters of Islamic Law deems it necessary to give a translation in modern Turkish in the title itself: 'Islam Hukukunda Müste'men (Yabancılar) Hukuku (Dört Halife Dönemi)' (The Law of Foreigners (Foreigners) in Islamic Law (Period of the Four Caliphs)). ${ }^{56}$ In the last decades, ecnebi has been less used too, being quoted as a translation of 'foreign' in many bilingual dictionaries, but often in the second position. ${ }^{57}$ In some of them, the word is not even mentioned. ${ }^{58}$ Interestingly enough, it seems as if ecnebi has been replaced by another Ottoman word: yabancı.

In the Ottoman Empire, yabancı was less and more recently used than ecnebi. ${ }^{59}$ Some modern dictionaries devoted to Ottoman history do not mention it. ${ }^{60}$ Although at the very end of the Empire, the word became much more used, from Şemseddin Sami who translated 'étranger' first by yabancı, second by ecnebi, ${ }^{61}$ to Ziya Gökalp who made extensive use of it. ${ }^{62}$ Yabancl was first addressed as the Turkified form (by the suffix $-\mathrm{Cl}$ ) of an Arabic word also used in Ottoman: 'Jebân'. In Yakup Karaosmanoğlu's famous novel, yaban/yabani (wild, stranger) is precisely the word the people of a little village located in the region of Haymana, Mihalıççık and Sivrihisar utilize to designate outsiders. ${ }^{63}$ Ecnebi refers to a kind of outwardness, designating for instance a person who could not have access to the Harem. ${ }^{64}$ Similarly, yabanlık designates 'visiting clothes'. ${ }^{65}$ Both words are characterized by remoteness, estrangement and lack of privacy. ${ }^{66}$ However, yabancl has much more negative connotations. As in Persian, ${ }^{67}$ a yabanci comes from a 'savage' world $(y a b a n i)^{68}$ located outside of the ecumene and deprived of any cities or dwellings (destertum, campus, aut sylva, ab habitationibus). ${ }^{69}$ To the lexicographer Barbier du Meynard, a yabancı is less a foreigner or a stranger than a savage, rude and uneducated man (sauvage, grossier, sans éducation). ${ }^{70}$ In Namık Kemal's play Vatan yahut Silistre ('The Motherland otherwise Silistra', 1873) that narrates how a group of Muslim Ottoman civilians volunteer to join the army and defend Silistra (now in northern Bulgaria) besieged by the Russians during the Crimean War (1853-1856), yabancı designates the 'enemy' (düşman) the 'motherland' (vatan) has to fight against.

I was so wrong! I thought only a handful would die for the motherland. It seems that's what the enemy had assumed. Yes! The Ottomans talk as if they have no concern for the motherland, they seem so indifferent, you'd think they are made of stone. But when you show them the enemy, when they realize that the holy soil of the motherland is to be trampled under the filthy feet of the foreigners, then something happens to these people. At that time, the differences between me and the laziest peasant are dissolved. At that time, those wretched Turks wrapped in coarse wool and felt, those gentle, kind-faced peasants, the desperate people whom we do not tend to tell apart from the harnessed oxen, disappear completely. In their place appear the spirit of Ottomanness, and the spirit of heroism. ${ }^{71}$

Interestingly enough, even if Namık Kemal does not explicitly relate yabancı either to Russians or Christians, he clearly associates the Ottomans/Ottomanness (Osmancılık) both with the 'Turks'/'villagers' (köylüler) and the Muslim religion: the most heroic figure in the play is named Islam Bey and the volunteers assembled in the Silistra castle are all Muslim 
subjects. As Ahmet Ersoy puts it: 'While, in theory, the novel Ottoman notion of patrie demanded the allegiance of all ethno-religious elements in the empire, the sentiments that actually went into the making of the idea perceptibly appealed to the dominant Muslim community. ${ }^{72}$ We will address to what extent this conception prevailed under the Turkish Republic.

\section{Ecnebiden Yabanciya ('From foreigner to foreigner'): the republic}

On the Turkish Language Society (Türk Dili Kurumu (TDK)) website, since 'Ottoman' is not taken into account, ecnebi is logically designated as Arabic. ${ }^{73}$ Previously, the word was not selected either in any official compendium such as the Derleme sözlügü ('Anthological dictionary') or in the Tarama sözlüğ̈̈ (id.) published, respectively, in 1963 and $1967 .{ }^{74}$ In the numerous entries devoted to yaban, the word was quoted as only associated with yabancı or garip (stranger). ${ }^{75}$ However, as was the case for many Ottoman words, it passed through the Caudine Forks of the linguistic reform with the result that it can now be found in many dictionaries. ${ }^{76}$ Yabancl came to replace it, albeit a Persian-origin word identified as such in the official dictionary published by the TDK. ${ }^{77}$ However, it initially benefited from a Turkish suffix that made it more compatible with the öz türkçe policy implemented then. It was inscribed in a particularly diversified lexical enterprise: yaban, yabani and yabanci alone spawned no less than 50 neologisms. Most of them remained unused by Turkish citizens. ${ }^{78}$

On the one hand, the word was provided with a circumscribed political definition: a yabancı was anyone who did not possess Turkish 'citizenship' (uyrukluk, vatandaşlık). ${ }^{79}$ On the other hand, it kept many of its previous meanings as much as it crystallized those encapsulated by forgotten Ottoman words, such as ecnebi (defined as tebaa, from another devlet, 'State'). ${ }^{80}$ If a yabancı was from another nation, he could also be characterized as such as being a member of another family, another house, or depicted as an unknown person. ${ }^{81}$ Conversely, to quote a famous example, Boris Johnson, former Mayor of London and appointed Foreign Secretary in 2016, is a great-grandson of Ali Kemal, who was a harsh antikemalist columnist. Recently, a Turkish newspaper identified him as ' $12.5 \%$ Ottoman'. As a result, 'he is not a yabancl', but someone any Turk could be 'familiar with'. ${ }^{82}$ Rather unsurprisingly, this to be or not to be yabancı paradigm ended up as particularly fit to nurture any kind of conspiracy theory - 'which is often what passes for a philosophy in history in contemporary Turkey' as Şerif Mardin said once. ${ }^{83}$ Beyaz Efendi, a bestseller in Turkey by S. Yalçın, is a good example of it, identifying the links between various segments of a 'foreign influence' (yabancı etkisi) from outside and operating inside the nation through either 'white Turks' or 'white Muslims'. ${ }^{44}$ Such a framework favours the national ethos as much as it fits a political agenda. The more diverse a yabancı is outside or inside, the more 'secret' (sırrı) and 'influential' (etkili) he might be inside and the more unified the milli has to be inside. This equation becomes complicated when insiders end up as foreigners outside, or more problematically, inside.

A Turkish citizen might be considered someone from outside, i.e. not from here, i.e. garip in Turkish. In the aforementioned novel Yaban, a Turkish officer asks the villagers about a retired officer who lived a few years among them before he finally quit. They reply they have no idea. Realizing that such an answer astonishes the officer, one of them finally admits: 'But, he was just a stranger like you'. ${ }^{85}$ Far from being specific to Turkey, this story 
echoes many cases addressed by historians in other countries. ${ }^{86}$ In nineteenth-century Central Europe alike, someone who was not from a particular heimat was easily considered a stranger. But in Turkey, there is something else that relates yabancllik not only to local identity but to national belonging. Anyone might feel a stranger in his own country. This is exactly what the famous conservative poet Necip Fazıl relates in Sakarya (1949).

Öz yurdunda garipsin, öz vatanında parya!

You are a stranger in your own homeland, a pariah in your own fatherland!

In a speech delivered on 21 September 2013, President R. T. Erdoğan himself quoted this verse, echoing a feeling that many Muslim Turks might experience sometimes: being a stranger for not being a 'White Turk' (Beyaz Turk).

\section{Conclusion}

According to the Constitution of 1924, after the Republic was created, any Ottoman citizen (tebaa) living in the national boundaries became bound to the Turkish State, regardless of his/her own religion. Consequently, any non-Muslim citizen is Turkish. However, he/she could not call himself/herself a Turk as any of his/her Muslim fellows could, since nationality was not exactly homothetic to citizenship during the Kemalist period. ${ }^{87}$ In other words, even if he/she has always been politically represented by the Millet Meclisi (National Assembly), as a zimmi's descendant, he/she has been not only ideologically but also, and more surprisingly, legally kept apart from the Turkish millet, as E. Öktem demonstrates in his article. My point was to address to what extent this situation resulted not only in the transformation of Ottoman categories designating Muslims and non-Muslims, but also in the differentiation between imperial citizens and foreigners. After the Republic was instituted, some of these categories faded away while others were insufflated with articulated or contradictory notions. Among these categories, the word yabancl clearly differentiated Turkish citizens from the rest of the world, as in any other country. The distinction milli/ ecnebi was replaced by the distinction türk/yabancı. Interestingly enough, this change occurred in the 1920s, at a time when many citizens had to make a place for themselves. As Lerna Emekçioğlu has recently shown, the Armenian citizens of Istanbul (Bolsahay), for instance, had to reconstruct their communities within a country that still considered them traitors. Although many of these Republican zimmi 'recovered their identity within these drastically changing political conditions', ${ }^{88}$ they did not become Turks the way their Muslim fellow citizens did. Surely, as many other non-Muslim communities who were left without any real prospect of full integration on an equal basis, they were never regarded as yabancl in the way others from foreign countries were. However, they were not considered to be part of Turkey's national community either.

\section{Acknowledgments}

Olivier Bouquet wishes to express his deep thanks to Emre Öktem for his bibliographical help and precious remarks on Republican Law, Emmanuel Szurek and Edhem Eldem for their useful comments, and Malika McCosh and Muriel Domenach for their corrections. 


\section{Disclosure statement}

No potential conflict of interest was reported by the author.

\section{Notes}

1. 'Serap öğretmen çeşmenin üzerindeki yazıya dikkat etti: 'Barad oğlu Mıgdıs Hayratı' yazıyordu. Bir anlam veremedi. Yabancı bir kelimeydi ama acaba ne demekti? Namaz için abdest alan Hacı Amca ayrıca eğilip çeşmenin kurnasından kana kana su içti. 'Elhamdüllah' dedikten sonra. 'Toprağın bol olsun Mıgdıs Efendi' diye mırıldandı. Bu arada Serap öğretmene dönerek anlatmaya başladı: - Öğretmen kızım, bu çeşmeyi tamir ettiren Ermeni'nin adıdır Mıgdıs. Bir Osmanlı tebaasıymış. Vakıf kurmuş. Evet, bu toprakların gayrımüslim insanları da çeşitli vakıflar kurmuşlar. Serap öğretmen yeni bir şey daha öğrenmiş̦ti'. The vakf is mentioned as 'Magdis Kiregos (Mığdıs) Vakfı; kurucunun lakabı: Baradoğlu (1277 H., 1860 M.)' (Tarihte Ilginç Vakıflar (Ankara: Vakıf Genel Müdürlügü Yayınları, 2012), p.23).

2. Vakıf Medeniyeti ve Șehir (Ankara: Vakıf Genel Müdürlügüü Yayınları, 2013); M. Yıldız, Balkanlar'daki Osmanlı Vakıf Mirasından Amca Hasan Ağa Vakfı (Istanbul: Rağbet, 2012).

3. As a recent example of it, see Dünya Vakıflar Konferansı. 23--24 Eylül 2013. Istanbul (Ankara: Vakıflar Genel Müdürlügü, 2014).

4. I want to thank Araks Sahiner-Erdem for this indication.

5. See my Les noblesses du nom. Essai d'anthroponymie ottomane (Turnhout: Brepols, 2013).

6. 'Est Turc celui qui désire et aime l'être' (quoted in Tekin Alp, Le Kémalisme (Paris: Alcan, 1937), p.254).

7. 'Pour appartenir à la même Nation, il n'est pas indispensable d'appartenir à la même race et à la même religion, mais parler la même langue, avoir la même culture et le même idéal' (Ibid., p.255).

8. On the limitations and contradictions of these policies, see S. Akgönül, Les Grecs de Turquie: processus d'extinction d'une minorité de l'âge de l'État-nation à l'âge de la mondialisation (Paris/ Louvain-La-Neuve, L'Harmattan/Bruylant-Academia, 2004); A. Aktar, Vergisi ve 'Türkleștirme' Politikaları (Istanbul: Illetişim, 2000); S. Aslan, 'Incoherent State: The Controversy over Kurdish Naming in Turkey', European Journal of Turkish Studies, Vol.10, 2009 (http://ejts.revues.org/ index4142.html); S. Aslan, Nation-Building in Turkey and Morocco: Governing Kurdish and Berber Dissent (Cambridge: Cambridge University Press, 2014); M. Baer, 'The Double Bind of Race and Religion: The Conversion of the Dönme to Turkish Secular Nationalism', Society for Comparative Study of Society and History, Vol.46, No.4, Oct. 2004, pp.682-708; M. Baer, 'Turkish nationalism and the Dönme', in H.-L. Kieser (ed.), Turkey Beyond Nationalism.Towards Post-Nationalist Identities (London: I. B. Tauris, 2006), pp.67-73; M. Baer, The Dönme: Jewish Converts, Muslim Revolutionaries, and Secular Turks (Stanford: Stanford University Press, 2010); R. Bali, Cumhuriyet Yıllarında Türkiye Yahudileri: Bir Türkleştirme Serüveni (Istanbul: Illetişim, 1999); S. Cağaptay, Islam, Secularism, and Nationalism in Modern Turkey. Who is a Turk? (New York: Routledge, 2006); H. Eissenstat, 'Turkic Immigrants/Turkish Nationalism: Opportunities and Limitations of a Nationalism in Exile', The Turkish Studies Association Bulletin, No.25/2-26/1 (2001-2002), pp.25-50; H. Eissenstat, 'Metaphors of Race and Discourse of Nation: Racial Theory and the Beginnings of Nationalism in the Turkish Republic', in P. Spickard (ed.), Race and Nation: Ethnic Systems in the Modern World (New York: Routledge, 2005), pp.239-56; L. Emekçioğlu, Recovering Armenia: The Limits of Belonging in Post-Genocide Turkey (Stanford: Stanford University Press, 2016); C. Guttstadt, Türkiye, Yahudiler ve Holokost (Istanbul: Iletişim, 2012); Ç. Okutan, Bozkurt'tan Kur'an'a Milli Türk Talebe Birliği (MTTB) 1916-1980 (Istanbul: İstanbul Bilgi Üniversitesi, 2004); T. Suciyan, The Armenians in Modern Turkey: Post-Genocide Society, Politics and History (London: I. B. Tauris, 2011).

9. On the ongoing dilemma of the management of diversity in Turkey from a historical and legal perspective, see D. Bayır, Minorities and Nationalism in Turkish Law (New York: Routledge, 2013).

10. To quote a book, albeit dedicated to modern art issues (A. Antmen, Hale Tenger, içerdeki yabancı. Stranger within (Istanbul: Yapı Kredi Yayınları, 2007)).

11. Türkçe/Osmanlıca-Ingilizce Redhouse Sözlüğ̈̈ (Istanbul: Sev, 1997), p.789. 
12. On the Muhacirin Komisyonu (Commission of Refugees, 1860) that took over Caucasian refugees, see A. Saydam, Kırım ve Kafkas Göçleri (1856--1876) (Ankara: Türk Tarih Kurumu, 1997), pp.105-86.

13. Türkçe/Osmanlıca-Ingilizce Redhouse Sözlügü, p.405. Scrutinizing the catalogue of the Archives of the Turkish Republic (Cumhuriyet Arşivi), N. Uzman has found that muhacir and göçmen were, respectively, quoted 450 and 120 times for the 1923-1934 period and 40 and 140 for the 19341937 period ('Türkiye'nin Mülteci ve Muhacir Politikaları (1934-1947)' (PhD dissertation, Gazi University, Ankara, 2013), pp.6-7).

14. According to the Sharia or Koranic Law, the legal status of non-Muslim subjects was characterised by the obligation to pay an individual tribute or poll-tax (djizye or kharadj) and by various symbolic forms of subjection.

15. T.-X. Bianchi, Dictionnaire Français-Turc (Paris: Dondey-Dupré, 1843), Vol.1, p.661. The author also associates 'ecanib u agyar' with 'étrangers, en parlant de ceux qui n'ont pas de famille'.

16. Türkçe/Osmanlıca-Ingilizce Redhouse Sözlüğ̈̈, p.834.

17. On openness and permeability to aliens, see E. Eldem, 'Foreigners at the Threshold of Felicity: the Reception of Foreigners in Ottoman Istanbul', in D. Calabia and S.T. Christensen (eds.), Cultural Exchange in Early Modern Europe, Vol.Il, Cities and Cultural Exchange in Europe, 1400--1700 (Cambridge: Cambridge University Press and European Science Foundation), 2007, pp.114-31.

18. D. Panzac, 'Démographie', in F. Georgeon, N. Vatin and G. Veinstein (eds.), Dictionnaire de I'Empire ottoman (Paris: Fayard, 2015), pp.235-40.

19. B. Lewis, The Emergence of Modern Turkey (Oxford: Oxford University Press, 1968, 2nd ed.), p.344, footnote 36.

20. 'Bir din ve mezhebde bulunan cemaat; millet-i islam' (Ş. Sami, Kamus-i Türki (Istanbul: İkdam, 1317/1900), p.1400).

21. A. Yıldız, 'Ne Mutlu Türküm Diyebilene'. Türk Ulusal Kimliğinin Etno-Seküler Sınırları (1919--1938) (Istanbul: Iletişim, 2001), pp.50-52.

22. -Peki bu bayrak kimin bayrağı Dursun? dedim. Bu Türk dedikleri kim?

- ?! (...)

-Sen hiç Türk görmedin mi? (...)

-Köye hiç gelmedi ki bay öğretmem, dedi.

-Kim gelmedi?

-O işte, Türk dediğin.

-Peki sen nesin oğlum?

-Müslümanım öğretmenim.

-Kimden belledin bunu?

-Hoca Efendi dediydi ki, biz dediydi, hepimiz Müslümanız!

-Oğlum Müslümansın, anladık. Hepimiz Müslümanız. O bizim dinimiz. Hangi milletteniz biz? Senin bir milletin yok mu?

-Bilmiyom bay öğretmem...." (S. Arısoy, Karapürçek (Istanbul: Varlık Yayınevi, 1958), p.80; my translation).

23. A. Yıldız offers a detailed study on 'kök-paradigmaları' related to the conceptions of Turkish nationality and citizenship ('Ne Mutlu Türküm Diyebilene', pp.126-54; quotations from this author).

24. See E. Eldem, 'Reshuffling Nationality and Ethnicity. The Ottoman Bank Staff from Empire to Republic', in T. de Graaf, J. Jonker and J.-J. Mobron (eds.), European Banking Overseas, 19th--20th Century (Amsterdam: ABN AMRO Historical Archives, 2002), pp.179-211.

25. O.J. Schmitt, Les Levantins. Cadres de vie et identités d'un groupe ethno-confessionnel de l'Empire ottoman au «long » $19^{e}$ siecle (Istanbul: Isis, 2007), p.56. As an example of dynamic frenk mahallesi (Frank district) in Salonika, see M. Anastassiadou, 'Les Occidentaux de la place', in G. Veinstein (ed.), Salonique 1850--1918. La ville des Juifs et le réveil des Balkans (Paris: Autrement, 1992), pp.143-52.

26. According to A. Tietze, the word was used by Ferec and Mustafa Ali, respectively, during the fifteenth and sixteenth century (Tarihi ve Etimolojik Türkiye Türkçesi Lugatı (Istanbul, Vienna: Simurg, Österreichische Akademie der Wissenschaften, Vol.1, 2002), p.687). 
27. F. Meninski, Lexicon Arabico-Persico-Turcicum (Vienna: losephi Nobilis de Kurzböck, 1780), Vol.1, p.47.

28. A firman dated Ev. M. 1061 (Jan. 1651) orders that someone 'from outside' (ecnebiden) should be hired as an administrator (mütevelli) of an imperial foundation (Haremeyn vakfi), specifying that he should not be related to places where tax resources (mukataa) were auctioned (Evkâf-I Hümayun Müfettişliği Mahkemesi Şer'iyye Sicili, 48, 292). I want to thank Kenan Yıldız for having generously shown this document to me.

29. J.-B. Belot, Dictionnaire Français-Arabe (Beirut: Imprimerie catholique, 1952), p.465.

30. Düstur I/1 (Istanbul: Matbaa-i Amire, 1289/1872), pp.16-8.

31. D. Kélékian, Dictionnaire turc-français (Istanbul: Mihran, 1911), p.53.

32. F. Mehdi, Imtiyazat-ı Ecnebiyyenin Tatbikat-ı Hazırası (Samsun: Matbaa-i Cemil, 1325/1909).

33. Eldem, 'Foreigners'.

34. H. Inalcık, 'The Ottoman Economic Mind and Aspects of the Ottoman Economy', in M. Cook (ed.), Studies in the Economic History of the Middle East (London: Oxford University Press, 1970), pp.207-18.

35. According to the official guide, the most ancient registers kept in the Prime Minister Archives were set up in 1567, and the latest in 1913 (Başbakanlık Osmanlı Arşivi Rehberi (Ankara: Başbakanlık Devlet Arşivleri Genel Müdürlügü, 2010), pp.41-7). For an example of transcription of a late Ottoman register, see Ö. Erdinç, '003 ve 003M Numaralı Düvel-i Ecneniye Defterlerinin Transkripsyonu ve Değerlendirmesi' (Master thesis, Muğla Sıtkı Koçman Üniversitesi, Muğla, 2015).

36. Ecnebi Anonim ve Sermayesi Eshama Münkasem Şirketler ile Ecnebi Sigorta Şirketleri Kanun-i Muvakkati, Istanbul (Istanbul: Hukuk Matbaası, 1339/1341).

37. M.Z. Pakalın, Osmanlı Tarih Deyimleri ve Terimleri Sözlüğü (Istanbul: Millî Eğitim Bak. Yay., 1993), Vol.1, p.500.

38. Türkçe/Osmanlıca-Ingilizce Redhouse Sözlüğ̈̈, p.325.

39. N. Mallouf, Dictionnaire Français-Turc (Paris: Maisonneuve, 1881, 3rd ed.), p.291.

40. In Arabic alike (Belot, Dictionnaire, p.465).

41. S. Bey, Dictionnaire français-turc (Istanbul: Mihran, 1898, 2nd ed.), p.780.

42. F. Steingass, A Comprehensive Persian-English Dictionary (London: Routledge and Kegan Paul, 1977), p.19.

43. H. Avni, 1908'de Ecnebi Sermayesine Karşı Illk Kalkınmalar (Istanbul: Akşam Matbaası, 1935); D.Y. Cetinkaya, The Young Turks and the Boycott Movement: Nationalism, Protest and the Working Classes in the Formation of Modern Turkey (London: I. B. Tauris, 2013).

44. 'Ecnebi Anonim ve Sermayesi Eshama Münkasim Şirketler ile Ecnebi Sigorta Şirketleri Hakkında Kunun-i Mivakkat', 30 Teşrin-i sani 1330, Düstur, Il. Tertip (Istanbul: Matbaa-i Amire), Vol.7, pp.142-8.

45. Z. Toprak, Milli iktisat-Milli Burjuvazi (Istanbul: Tarih Vakfı, 1995), p.64.

46. Ibid., p.65.

47. R.L. Chambers, 'Ahmed Cevdet Paşa: The Formative Years of an Ottoman Transitional' (Unpubl. $\mathrm{PhD}$ dissertation, Princeton, 1968), p.60.

48. H. Sadoğlu, Türkiye'de Ulusçuluk ve Dil Politikaları (Istanbul: Bilgi Üniversitesi Yayınları, 2003).

49. 'Sâir elsine-i ecnebîyi öğrendiğimiz gibi Arabî ve Fârisîyi de öğrenebiliriz' (A. Cevat [Emre], Türkçe Sarf ve Nahiv. Eski Lisân-ı Osmânî Sarf ve Nahiv, in G. Sağol, E. Şahin and N. Yıldız (eds.) (Ankara: Türk Dil Kurumu Yayınları, 2004), pp.3-4.

50. Y.Z. Öksüz, Türkçenin Sadeleşme Tarihi, Genç Kalemler ve Yeni Lisan Hareketi (Ankara: Türk Dil Kurumu Yayınları, 1995), p.19; E. Szurek, 'Gouverner par les mots. Une histoire linguistique de la Turquie nationaliste' (PhD, EHESS, Paris, 2013), pp.100-102.

51. I am indebted to E. Szurek who provided me with valuable information.

52. 'Gökalp sums up his requirements in the matter of linguistic reform in the triple formula: modernization and Europeanization of the language in respect of notions, Islamization in respect of scientific terms, and Turkification in respect of all other words, and of grammar, syntax and orthography' (U. Heyd, Foundations of Turkish Nationalism: The Life and Teachings of Ziya Gökalp (London: Luzac \& Company Ltd. and the Harvill Press Ltd., 1950), pp.115-21, p.119). 
53. 'Bu esası ecnebi kelimelere de teşmil ederek fasahatçilerin sigara, jaket, Evropa şeklinde yazdıkları bu kelimeleri, halkın telâffuzu vechile (cigara, caket, Avrupa) yazmak lâzımdır' (Z. Gökalp, Türkçülüğ̈̈n Esasları, in M. Kaplan (ed.) (Ankara: Kültür Bak. Yayınları, 1990), p.113).

54. Kamus-i Türki. Kaffe-i Lugat-ı Türkiye ile lisan-ı Türkide Müstamel Kelimat ve Istılahat-ı Arabiye ve Farisiye ve Ecnebiyeyi Cami Olarak Lisanımızın Mükemmel Lügat Kitabıdır (Istanbul: İkdam, 1317/ 1899-1900).

55. It is nowhere to be found in the Çağdaş Türkçe-Ingilizce Redhouse Sözlüğü (Istanbul: Sev, 1983) whereas ecnebi has an entry, p.111.

56. H.S. Yeter, 'İslam Hukunda Müste'men (Yabancılar) Hukuku (Dört Halife Dönemi)' (Unpub. PhD thesis, Marmara University, Istanbul, 2002).

57. T. Saraç, Büyük Fransızca-Türkçe Sözlük (Istanbul: Adam, 1976), p.555; K. Steuerwald, AlmancaTürkçe Sözlük (Wiesbaden: Otto Harrassowitz, 1974), p.228; Ingilizce-Türkçe Redhouse Sözlüğü (Istanbul: Sev, 2006), p.380.

58. In the Büyük Sözlük (Istanbul: Fono, 2004), ecnebi, albeit quoted in Turkish, is not mentioned at the entry 'étranger' (p.282, p.902). Yabancı does not appear in F. Devellioğlu, Osmanlıca-Türkçe Ansiklopedik Lûgat (Istanbul: Aydın, 1993).

59. 'Extraneus, advena, peregrinus' (Meninski, Lexicon, Vol.IV, p.1163). In his Kamus-i Türki (p.1520), Ş. Sami offers an entry for yaban, not for yabancı, whereas he translates 'étranger' by 'yabancı' first in his Dictionnaire français-turc (p.780).

60. As examples of omissions, see Pakalın, Osmanlı; Devellioğlu, Osmanlıca; M. Kanar, Osmanlı Türkçesi Sözlüğ̈̈ (Istanbul: Sev, 2009); F. Yılmaz, Osmanlı Tarih Sözlüğü (Istanbul: Gökkubbe, 2010).

61. S. Bey, Dictionnaire français-turc, p.780.

62. Z. Gökalp, Türkçülügün Esasları, p.114.

63. Y.K. Karaosmanoğlu, Yaban (Istanbul: Iletişim, 1983), p.16 (1st ed.: 1932).

64. Yılmaz, Osmanlı, p.146.

65. Ibid., p.691.

66. Ecneb: 'uzaklaştırılmış' (Y. Çağbayır, Ötüken Türkçe Sözlük (Istanbul: Ötüken, 2007), Vol.2, p.1358; Y. Kocabay, Türkçe-Fransızca Büyük Sözlük (Ankara: Okutman, 1991), p.226; D. Kélékian, Dictionnaire turc-français (Istanbul: Amedi Matbaası, 1928), p.1348).

67. Yabânî, 'waste, desolate, uncultivated'; yâban, 'desert' (Steingass, A Comprehensive, p.1528).

68. Kélékian, Dictionnaire, 1928, p.1348.

69. Meninski, Lexicon, Vol.4, p.1163.

70. C.B. du Meynard, Dictionnaire turc-français (Paris: Leroux, 1886), Vol.2, p.875.

71. 'Ne yanlış inançta imişim: Vatan yolunda ölecek kırk kişi yoktur, sanırdım! Galiba, düşman da, Osmanlıları benim gibi görmüş. Evet, Osmanlılar söz arasında vatanı umursamaz gibi görünürler. O kadar umursamaz gibi görünürler ki, konuştuğun adamı, taştan yapılmış, resim zannedersin. Hele, karşılarında bir düșman göster; hele, vatanın mukaddes topraklarını bir yabancının murdar ayağı ile çiğneyeceğini anlasınlar iște o vakit, halka başka bir hâl geliyor! Işte o vakit insan, en miskin köylü ile benim aramda hiç fark bulamıyor! iş̧te o vakit, o abalı kebeli Türkler, o tatlı sözlü, yumuşak yüzlü köylüler, o çifte koşulur öküzden fark etmek istemediğimiz biçâreler aradan bütün bütün kayboluyor dar yerlerine Osmanlılığın, kahramanlığı ruhu meydana çıkıyor' (N. Kemal, Vatan yahut Silistre (Ankara: Kültür Bakanlığı, 1990), p.56-7). Translation by A. Ersoy, in B. Trencsényi and M. Kopecek (eds.), National Romanticism: The Formation of National Movements, Vol.2, Discourses of Collective Identity in Central and Southeast Europe 17701945 (Budapest/New York: CEU Press, 2007), pp.486-93.

72. Ibid., p.487.

73. http://www.tdk.gov.tr/index.php?option=com_bts\&arama=kelime\&guid=TDK. GTS.576942eb102978.62848269.

74. Türk Dil Kurumu Yayınları, Ankara University Press, 1993 (2nd ed.).

75. Tarama Sözlügü (Ankara: Türk Dil Kurumu), p.4184.

76. i.H. Danişmend, Fransızca-Türkçe: Resimli Büyük Dil Kılavuzu (Istanbul: Kanaat Kitabevi, 1967), p.492, p.1469.

77. Türkçe Sözlük (Ankara: Türk Dil Kurumu, 1983), Vol.2, p.1263. 
78. Türkçe Sözlük (Ankara: Türk Dil Kurumu, 1983), Vol.2, pp.1263-4; Derleme Sözlügü (Ankara Ü. Basimevi, Türk Dil Kurumu Yayınları, 1993 (2nd ed.)), Vol.11, p.4112.

79. R. Aybay, Yabancılar Hukuku (Istanbul: İstanbul Bilgi Üniversitesi, 2005), p.12.

80. 'Bir başka milletle ilgili' (Büyük Lûgat ve Ansiklopedisi, Vol.11, 1973, p.682).

81. 'Tanınmayan' (Türkçe Sözlük (Ankara: Türk Dil Kurumu, 1983), Vol.2, p.1263).

82. 'Boris Johnson kim mi? Yabancı değil' (Özcan Tikit, 'Avrupa'yı Sarsan \%12,5 Osmanlı', Haber Türk, June 26 2016, pp.6-7).

83. Ş. Mardin, 'The Nakșibendi Order in Turkish History', in R. Tapper (ed.), Islam in Modern Turkey. Religion, Politics and Literature in a Secular State (London: I. B. Tauris, 1991), pp.121-4, p.122.

84. S. Yalçın, Efendi. Beyaz Türklerin Büyük Sırrı (İstanbul: Doğan Kitap, 2004); id., Beyaz Müslümanların Büyük Sırrı. Efendi-2 (i̇stanbul: Doğan Kitap, 2006).

85. 'Dee, sizin gibi yabanın biriydi' (Karaosmanoğlu, Yaban, p.16).

86. E. Weber, Peasants into Frenchmen: The Modernization of Rural France 1870--1914 (Stanford: Stanford University Press, 1976).

87. As shown in Emre Öktem's article.

88. L. Emekçioğlu, Recovering Armenia. 